\title{
Coagulation Biomarkers in Women with Recurrent Miscarriage and Polycystic Ovarian Syndrome: Systematic Review and Meta-Analysis
}

\section{Koagulationsbiomarker bei Frauen mit habitueller Abortneigung und polyzystischem Ovarsyndrom: eine systematische Übersicht und Metaanalyse}

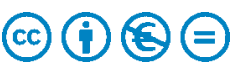

Authors

Marcelo Borges Cavalcante ${ }^{1}$, Manoel Sarno², Candice Torres de Melo Bezerra Cavalcante ${ }^{3}$, Edward Araujo Júnior ${ }^{4}$, Ricardo Barini ${ }^{5}$

Affiliations

1 Department of Obstetrics and Gynecology, Fortaleza University (UNIFOR), Fortaleza-CE, Brazil

2 Department of Obstetrics and Gynecology, Federal University of Bahia (UFBA), Salvador-BA, Brazil

3 Pediatric Cardiac Center, Messejana Hospital Dr. Carlos Alberto Studart Gomes, Fortaleza-CE, Brazil

4 Department of Obstetrics, Paulista School of Medicine, Federal University of São Paulo (EPM-UNIFESP), São PauloSP, Brazil

5 Department of Obstetrics and Gynecology, State University of Campinas (UNICAMP), Campinas-SP, Brazil

Key words

abortion, biomarker, disturbed ovarian function, polymorphism

Schlüsselwörter

Fehlgeburt, Biomarker, gestörte Ovarfunktion,

Polymorphismus

received 27.1.2019

revised 22.3.2019

accepted 26.3.2019

Bibliography

DOI https://doi.org/10.1055/a-0884-3212

Geburtsh Frauenheilk 2019; 79: 697-704 @ Georg Thieme

Verlag KG Stuttgart · New York | ISSN 0016-5751

Correspondence

Prof. Edward Araujo Júnior, PhD

Department of Obstetrics, Paulista School of Medicine,

Federal University of São Paulo (EPM-UNIFESP)

Rua Belchior de Azevedo, 156 apto. 111 Torre Vitoria,

São Paulo-SP, CEP 05089-030, Brazil

araujojred@terra.com.br

\section{ABSTRACT}

Introduction Pregnant women with polycystic ovarian syndrome (PCOS) have high risk of pregnancy loss. Pathophysiological mechanisms appear to be associated with obesity, hormonal factors, or blood clotting disorders. Our aim is to perform a systematic review and meta-analysis on the relationship between coagulation disorders and risk of recurrent miscarriage (RM) in patients with PCOS and to identify coagulation biomarkers for this condition.

Material and Methods PubMed and MEDLINE databases were searched for publications in English language. The search terms used included "RM", "polycystic ovary syndrome", "coagulation disorders", and "thrombophilia". Odds ratios (ORs) and 95\% confidence intervals (Cls) for miscarriage in different RM groups (with and without PCOS).

Results A total of 575 publications including the search terms were identified. Six studies were included for qualitative analysis, and five were included for quantitative analysis (metaanalysis). We found no association between RM and inherited thrombophilias in patients with PCOS: (1) Factor V Leiden (OR, 0.74 ; $95 \% \mathrm{Cl}, 0.38-1.45 ; \mathrm{p}=0.38$ ); (2) C677T methylenetetrahydrofolate reductase polymorphism (MTHFR) (OR, 1.01; 95\% Cl, 0.64-1.59; $\mathrm{p}=0.97$ ); and (3) A1297C MTHFR polymorphism (OR, $1.08 ; 95 \% \mathrm{Cl}, 0.62-1.89 ; \mathrm{p}=0.77)$. Other potential biomarkers were identified, with emphasis on plasminogen activator inhibitor type 1 .

Conclusion Data available in the current literature revealed that there was no association between RM and inherited thrombophilias in patients with PCOS. RM patients with PCOS have a high risk of thromboembolic events.

\section{ZUSAMMENFASSUNG}

Einleitung Schwangere Frauen mit polyzystischem Ovarsyndrom (PCOS) haben ein hohes Fehlgeburtsrisiko. Es scheint eine Assoziation zwischen den pathophysiologischen Mechanismen einerseits und Adipositas, hormonellen Faktoren und Koagulationsstörungen andererseits zu geben. Ziel dieser Stu- 
die war es, eine systematische Übersicht und eine Metaanalyse über die Beziehungen zwischen Gerinnungsstörungen und dem Risiko wiederholter Fehlgeburten (RM) bei Patientinnen mit PCOS durchzuführen und die Koagulationsbiomarker für diesen Zustand zu identifizieren.

Material und Methode Die Datenbanken von PubMed und MEDLINE wurden nach englischsprachigen Publikationen zu diesem Thema durchsucht. Die hierfür verwendeten Suchbegriffe waren „RM“, „polycystic ovary syndrome“ (polyzystisches Ovarsyndrom), „coagulation disorders“ (Koagulationsstörungen) sowie „thrombophilia“ (Thrombophilie). Die Odds Ratios (ORs) und 95\%-Konfidenzintervalle (KIs) für Fehlgeburten wurden für die verschiedenen RM-Gruppen (mit und ohne PCOS) berechnet.

Ergebnisse Insgesamt wurden 575 Artikel mit diesen Suchbegriffen identifiziert. Sechs Studien wurden für die qualita- tive Analyse und 5 für die quantitative Analyse (Metaanalyse) herangezogen. Wir fanden keine Beziehung zwischen RM und einer vererbten Thrombophilie in Patientinnen mit PCOS: (1) Faktor-V-Leiden (OR, 0,74; 95\%-KI, 0,38-1,45; p=0,38); (2) C677T-Methylen-Tetrahydrofolat-Reduktase-Polymorphismus (MTHFR) (OR, 1,01; 95\%-KI, 0,64-1,59; $\mathrm{p}=0,97$ ), und (3) A1297C-MTHFR-Polymorphismus (OR, 1,08; 95\%-KI, 0,62$1,89 ; p=0,77)$. Es wurden andere potenzielle Biomarker ausgemacht mit einem Schwerpunkt auf den Plasminogen-Aktivator-Hemmer Typ 1.

Schlussfolgerung Die aus der aktuellen Literatur entnommenen Daten zeigten, dass es keine Assoziation zwischen RM und einer vererbten Thrombophilie bei Patientinnen mit PCOS gibt. RM-Patientinnen mit PCOS haben ein höheres Risiko für thromboembolische Ereignisse.

\section{Introduction}

Polycystic ovarian syndrome (PCOS), also known as polycystic ovarian disease and Stein-Leventhal syndrome, was first described in 1935 by Irving Stein and Michael Leventhal in an article published in the American Journal of Obstetrics and Gynecology entitled "Amenorrhea associated with polycystic ovaries". In the original publication, the authors described a series of cases in which seven patients had enlarged ovaries (diagnosed by transabdominal pneumonography) associated with menstrual changes, infertility, pain, or hyperandrogenism. The patients also presented with obesity (three patients), hirsutism (five patients), and acne (one patient) [1,2]. In 1939, the gestational outcomes of these seven patients were published: five patients became pregnant after surgery, one patient had a male factor present, and one was lost during follow-up after 11 months [3].

PCOS is the most common endocrine disorder in women of reproductive age. Its prevalence is variable, depending on the ethnic group and diagnostic criteria, and occurs in around 5 to $16 \%$ of women in reproductive phase of life [4]. Prevalence is higher among the following groups:

1. infertile and oligomenorrhagic women;

2. obese with or without insulin resistance;

3. history of type 1 , type 2 , or gestational diabetes;

4. history of premature adrenarche;

5. first-degree relatives with PCOS; and

6. use of anti-epileptic drugs [4,5].

PCOS is not only related to gynecological disorders (infertility and menstrual irregularity), as initially described by Stein and Leventhal, but is also associated with other pathologies such as cardiovascular disease, metabolic syndrome, obesity, type 1 and 2 diabetes mellitus, gestational diabetes, nonalcoholic steatohepatitis, obstructive sleep apnea, endometrial cancer, anxiety, depression, and eating disorders [6-8]. The relationship between PCOS and obstetric complications, neonatal outcome, and adult life after gestation in a mother with PCOS is not well understood [6, 7].
Recurrent miscarriage (RM) is defined as two or more pregnancy losses before 20 weeks of gestation [9]. The incidence of RM ranges from 0.5 to $2.3 \%$, and may vary due to different definitions and different methodologies used in the statistical calculation. However, an increase in the incidence of recurrent miscarriage has been observed [10]. Genetic alterations, uterine anatomical changes, hormonal disorders, and antiphospholipid syndrome (APS) are responsible for around half of the cases of RM, and the other half still remains without a clear diagnosis [11]. While the association between PCOS and RM is described in the literature, the mechanisms involved are not well defined [1214]. PCOS carriers have metabolic, endocrine (insulin resistance, dyslipidemia, obesity, chronic inflammation), and coagulation disorders that may be related to pregnancy loss [6, 15-17].

Since the late 1970s, when the relationship between APS and pregnancy loss was first described, studies have evaluated the relationship between blood coagulation and gestational pathologies. It is believed that thromboembolic events at the site of implantation and the placental bed provide the basis for the pathophysiology of pregnancy losses and other obstetric complications, such as preeclampsia, fetal growth restriction, fetal death, and preterm delivery $[18,19]$. The relationship between APS and RM is well established in the literature [20]. However, the relationship between hereditary thrombophilias and other thrombophilic disorders with RM remains unclear [21].

The aim of this systematic review and meta-analysis was to identify biomarkers of coagulation disorders in women with RM and history of PCOS, highlighting the possible pathophysiological mechanisms involved and the possible interventions that may reduce the risk of gestational loss in these patients.

\section{Methods}

This systematic review was performed using Preferred Reporting Items for Systematic Reviews and Meta-Analyses (PRISMA) [22]. PubMed and MEDLINE databases were searched for publications available up to and including October 2018. The search terms 


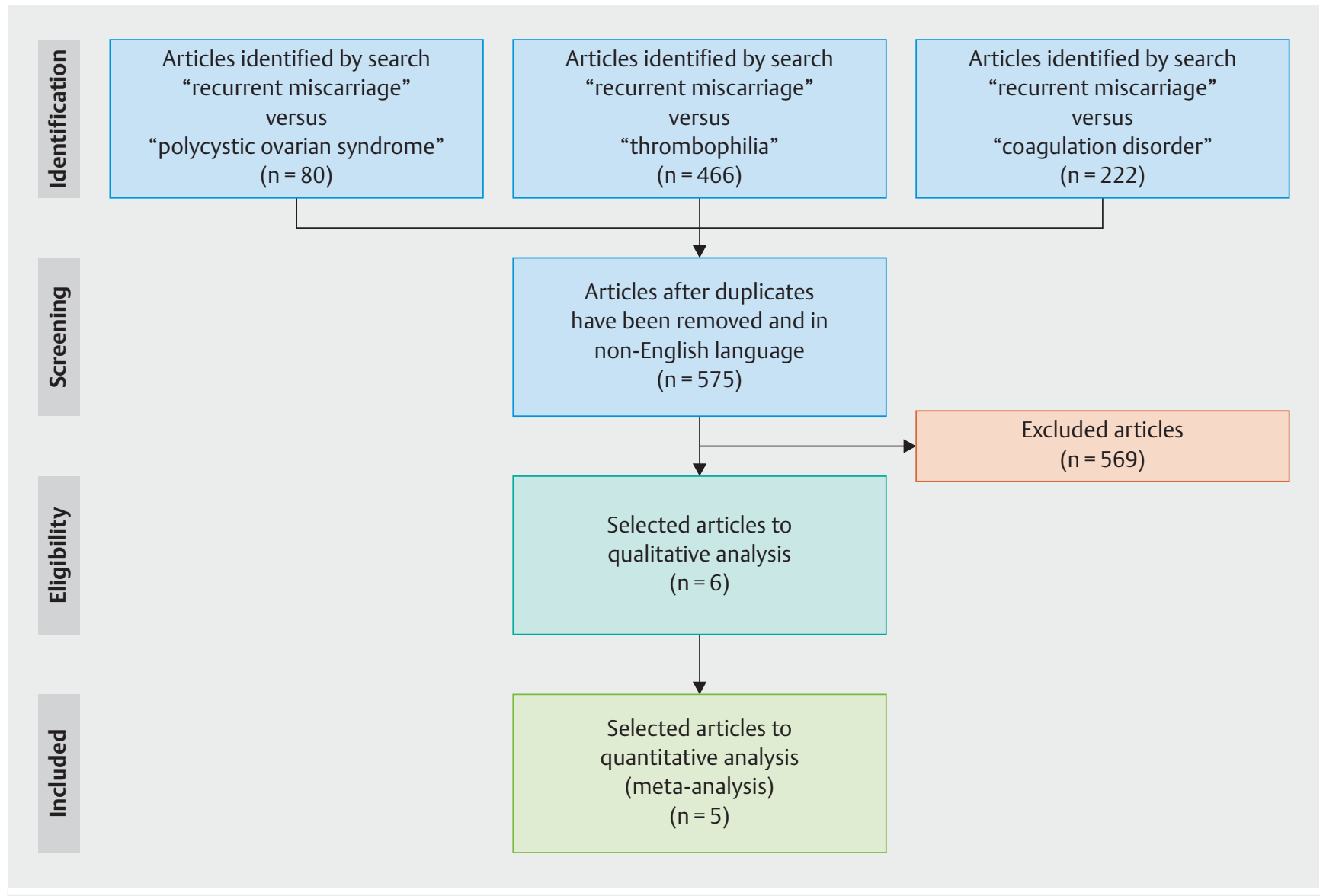

- Fig. 1 Flowchart of the search showing preferred reporting items used for the Systematic Reviews and Meta-Analyses (PRISMA).

used were "RM”, “polycystic ovary syndrome”, "coagulation disorders", and "thrombophilia".

Data extraction was performed by two reviewers. The title and abstracts of the articles identified in the initial search were independently evaluated according to the following inclusion criteria: type of study, population (women with a history of recurrent miscarriage and PCOS), risk factor assessment (coagulation disorder), and primary outcome (miscarriage). Articles were limited to studies using humans and published in English. Studies investigating physiopathological mechanisms were also evaluated and discussed.

Available data were imported into Review Manager, version 5.3.5 (The Cochrane Collaboration), for quantitative analysis.

\section{Results}

\section{Identified and selected studies}

Five hundred seventy five publications related to the search terms were identified. All animal studies and systematic review were excluded, and included only six studies that evaluated biomarkers of coagulation disorders in patients with RM and history PCOS ( $\vee$ Fig. 1). These six studies evaluated a total of 392 patients with RM and PCOS. Details of the studies included in the statistical analysis and discussion are described in $\downarrow$ Table 1. No prospective or intervention studies were identified. The six studies selected were observational case-control studies. The studies were conducted in different countries, including Iran (three studies), the United States (one study), Germany (one study), and Poland (one study), and were published in the period from 2003 to 2016 [2328].

The majority of studies were selected cases of RM using a history of three or more spontaneous pregnancy losses at less than 20 weeks of gestation [23-26]. Only the two most recent studies considered RM as the antecedent of two or more pregnancy losses at less than 20 weeks $[27,28]$. Most studies used the Rotterdam criteria for PCOS diagnosis [24-28], and only one study [23] used the National Institutes of Health (NIH) criteria.

\section{Coagulation biomarkers}

The first study to evaluate the relationship between coagulation disorders in patients with RM and history of PCOS was published by Glueck el al. [23]. They observed a higher prevalence of Factor $\checkmark$ Leiden (FVL) in patients diagnosed with RM and PCOS compared with the normal control group, but this was not more prevalent compared with the RM group without PCOS. The authors also observed a reduction in the fibrinolytic activity of patients with RM and PCOS, through high activity of the plasminogen activated in- 
- Table 1 Studies on coagulations disorders among women with polycystic ovarian syndrome (PCOS) with a history of recurrent miscarriage (RM).

\begin{tabular}{|c|c|c|c|c|}
\hline $\begin{array}{l}\text { Author, year } \\
\text { (country) }\end{array}$ & $\begin{array}{l}\text { Study } \\
\text { type }\end{array}$ & Groups & Biomarkers & Comments \\
\hline $\begin{array}{l}\text { Glueck et al., } 2003 \\
\text { [23] } \\
\text { (United States } \\
\text { of America) }\end{array}$ & $\begin{array}{l}\text { Case- } \\
\text { control }\end{array}$ & $\begin{array}{l}\text { PCOS-RM ( } 33 \text { Caucasian } \\
\text { women) } \\
\text { RM without PCOS } \\
\text { (16 Caucasian women) } \\
\text { Controls ( } 116 \text { healthy } \\
\text { Caucasian women) }\end{array}$ & $\begin{array}{l}\text { G1691A Factor V Leiden } \\
\text { G20210A prothrombin } \\
\text { C677T MTHFR } \\
\text { PAl-1 (4 G/5 G) gene polymorphism } \\
\text { Platelet glycoprotein PL A1A2 gene } \\
\text { mutations } \\
\text { Homocysteine } \\
\text { Proteins C, S, free S, antithrombin } \\
\text { Anticardiolipin antibodies IgG and IgM } \\
\text { Dilute Russel's viper venom time } \\
\text { Activated partial thromboplastin time } \\
\text { Factor VIII } \\
\text { Factor XI } \\
\text { Lipoprotein (a) } \\
\text { PAI-Fx }\end{array}$ & $\begin{array}{l}\text { The thrombophilic G1691A Factor V } \\
\text { Leiden mutation is associated with RM } \\
\text { in women with and without PCOS; } \\
\text { hypofibrinolysis (high PAI-Fx) is also } \\
\text { associated with RM in women with } \\
\text { PCOS. }\end{array}$ \\
\hline $\begin{array}{l}\text { Idali et al., } 2012 \\
\text { [24] } \\
\text { (Iran) }\end{array}$ & $\begin{array}{l}\text { Case- } \\
\text { control }\end{array}$ & $\begin{array}{l}177 \text { RM ( } 38 \text { women with } \\
\text { RM-PCOS, } 33 \text { with ovarian } \\
\text { PCOS-RM, and } 106 \text { RM } \\
\text { without PCOS, } 100 \text { female } \\
\text { controls) }\end{array}$ & $\begin{array}{l}\text { A1298C MTHFR } \\
\text { C677T MTHFR } \\
\text { PAI-1 (4 G/5 G) gene polymorphisms }\end{array}$ & $\begin{array}{l}\text { MTHFR A1298C and PAI-1 4 G/5 G mu- } \\
\text { tations were more prevalent in Iranian } \\
\text { women suffering from RM with and } \\
\text { without PCOS. }\end{array}$ \\
\hline $\begin{array}{l}\text { Moini et al., } 2012 \\
\text { [25] } \\
\text { (Iran) }\end{array}$ & $\begin{array}{l}\text { Case- } \\
\text { control }\end{array}$ & $\begin{array}{l}92 \text { women with RM-PCOS } \\
92 \text { women with RM without } \\
\text { PCOS. }\end{array}$ & $\begin{array}{l}\text { G1691A Factor V Leiden } \\
\text { Homocysteine } \\
\text { Proteins C, S, free S, antithrombin } \\
\text { Anticardiolipin antibodies IgG and IgM }\end{array}$ & $\begin{array}{l}\text { There was a trend toward higher } \\
\text { prevalence of protein } S \text { deficiency } \\
\text { in RM-PCOS women }(p=0.05) \text {. }\end{array}$ \\
\hline $\begin{array}{l}\text { Kazerooni et al., } \\
2013 \text { [26] } \\
\text { (Iran) }\end{array}$ & $\begin{array}{l}\text { Case- } \\
\text { control }\end{array}$ & $\begin{array}{l}60 \text { patients with RM-PCOS } \\
60 \text { patients with PCOS and } \\
\text { without RM } \\
60 \text { patients with RM and } \\
\text { without PCOS } \\
60 \text { healthy individuals }\end{array}$ & $\begin{array}{l}\text { Testosterone } \\
\text { Fasting insulin } \\
\text { Homocysteine } \\
\text { Plasminogen activator inhibitor } \\
\text { activity (PAI-Fx) } \\
\text { Protein C, Protein S, antithrombin } \\
\text { Activated protein C ratio (APCR) } \\
\text { Factor V Leiden } \\
\text { Prothrombin G20210A } \\
\text { MTHFR gene mutations }\end{array}$ & $\begin{array}{l}\text { Hyperinsulinemia, hyperandrogene- } \\
\text { mia, hypofibrinolysis, and hyper- } \\
\text { homocysteinemia, as well as APCR and } \\
\text { factor V Leiden mutations, are associ- } \\
\text { ated with RM in patients with PCOS. }\end{array}$ \\
\hline $\begin{array}{l}\text { Rogenhofer et al., } \\
2013 \text { [27] } \\
\text { (Germany) }\end{array}$ & $\begin{array}{l}\text { Case- } \\
\text { control }\end{array}$ & $\begin{array}{l}100 \text { PCOS patients } \\
\text { ( } 27 \text { no recorded pregnan- } \\
\text { cies; } 73 \text { RM), } 500 \text { fertile } \\
\text { women and } 533 \text { random } \\
\text { population } \\
\text { Controls }\end{array}$ & M2/ANXA5 Polymorphism & $\begin{array}{l}\text { M2/ANXA5 seems an independent RM } \\
\text { risk factor in PCOS patients that pro- } \\
\text { gressively correlates with the number } \\
\text { of first trimester pregnancies. }\end{array}$ \\
\hline $\begin{array}{l}\text { Szafarowska et al., } \\
2016[28] \\
\text { (Poland) }\end{array}$ & $\begin{array}{l}\text { Case- } \\
\text { control }\end{array}$ & $\begin{array}{l}76 \text { PCOS women } \\
\text { ( } 63 \text { RM and } 13 \text { infertility) } \\
56 \text { non-PCOS women } \\
\text { ( } 40 \text { RM and } 16 \text { infertility) }\end{array}$ & $\begin{array}{l}\text { A1298C MTHFR } \\
\text { C677T MTHFR }\end{array}$ & $\begin{array}{l}\text { MTHFR mutation was not associated } \\
\text { with PCOS in the Polish population. } \\
\text { There was correlation between the } \\
\text { MTHFR A } 1298 \text { C mutation and RM in } \\
\text { the non-PCOS group. }\end{array}$ \\
\hline
\end{tabular}

RM was defined as a history of three or more spontaneous pregnancy losses at less than 20 weeks of gestation [23-26]. RM was defined as the antecedent of two or more pregnancy losses at less than 20 weeks. [27,28] Rotterdam criteria for PCOS diagnosis. [24-28] National Institutes of Health (NIH) criteria for PCOS diagnosis [23].

hibitor (PAI-Fx) compared with the RM group without PCOS $(p=0.0363)$ and the normal control group $(p=0.0039)$. Age and body mass index among the RM groups (with or without PCOS) were similar, showing that fibrinolysis changes were independent of obesity [23].
Idali et al. [24] observed a higher prevalence of hereditary thrombophilias (A1298C methylenetetrahydrofolate reductase polymorphism [MTHFR A1298C] and PAI-1 4G/5G) in patients with a history of RM (with or without PCOS) compared with con- 
trols. However, the prevalence of these thrombophilias was similar compared with patients with RM with and without PCOS.

Moini et al. [25] compared the prevalence of the following thrombophilias in groups of RM patients with and without PCOS: protein $C$ deficiency, protein $\mathrm{S}$ deficiency, antithrombin deficiency, FVL, hyperhomocysteinemia, and APS. They identified at least one clotting disorder in $70.7 \%$ (65/92) of women with RM and PCOS compared with $47.8 \%$ (44/92) of patients with RM without PCOS $(p=0.002)$. Protein $C$ deficiency was the only thrombophilia that showed a higher prevalence in patients with RM and PCOS (21.7 vs. $10.9 \%, p=0.04$ ).

Kazerooni et al. [26] identified high levels of total testosterone, hyperhomocysteinemia, insulin resistance, increased PAl activity, and resistance to activated protein $C$ in women with RM and PCOS compared with women with RM without PCOS and the control group. Among the evaluated thrombophilias, the authors observed a relationship between FVL and RM, independent of the group (with or without PCOS). There was no significant difference between the groups regarding levels of protein $C$, protein $S$, and antithrombin.

The relationships between MTHFR polymorphisms (A1298C and C677T) and annexin A5 (M2/ANXA5) and RM in PCOS patients were evaluated by Szafarowska et al. [28] and Rogenhofer et al. [27]. MTHFR polymorphisms appeared to be unrelated to pregnancy loss in the group of PCOS patients, whereas M2/ANXA5 appeared to be an independent risk factor for pregnancy loss in PCOS patients.

Among the six studies that evaluated coagulation disorder biomarkers in patients with RM diagnosed with PCOS, it was only possible to use genetic biomarker (hereditary thrombophilias) data from five studies for statistical analysis. Rogenhofer et al. [27] were not included in the statistic analysis because it was the only study that evaluated M2/ANXA5. No statistical significance was found in relation to FVL ( $\triangleright$ Fig. 2 a) $[23,25,26]$ and MTHFR polymorphisms (A1298C and C677T) ( $\bullet$ Fig. 2 b and c) in RM patients with PCOS compared with patients with RM without PCOS $[24,26,28]$.

\section{Discussion}

PCOS is an endocrine condition initially described as a gynecological disorder associated with menstrual irregularity due to chronic anovulation and enlarged ovaries with the presence of multiple small cysts. PCOS has attracted much interest from researchers due to its reproductive and metabolic repercussions (glucose intolerance, obesity, diabetes, hypertension, metabolic syndrome, and cancer). Studies have shown that women with PCOS are at increased risk of changes to blood clotting via mechanisms that remain poorly understood $[2,15,17]$. It is possible that the metabolic alterations observed in these patients are involved in the pathophysiology of coagulation disorders, including obesity, chronic inflammatory process, excess androgen hormones, dyslipidemia, and insulin resistance [15].

Over the last decades, studies have described anomalies in blood coagulation in patients with PCOS, demonstrating an imbalance between the thrombogenic and antithrombogenic components of the coagulation system. Higher platelet number, higher mean platelet volume, platelet activation, higher levels of von Willebrand factor, elevated PAI-1, elevated asymmetric dimethyl-Larginine, elevated levels of D-higher tissue factor, faster thrombin generation, protein C deficiency, and lower levels of plasminogen activity are some of the changes seen in coagulation components in non-pregnant patients diagnosed with PCOS [15].

Physiologically, gestation is a prothrombotic state, which becomes more pronounced closer to term. Conditions other than pregnancy may also increase the risk of thromboembolic events in the gestational period. Shan et al. studied pregnant women with or without PCOS during the first trimester of pregnancy and observed that pregnant women with a previous diagnosis of PCOS had a higher procoagulant state due to a higher concentration of activated clotting factors VIII and activated X [29].

The possible relationship between thromboembolic events and RM, such as those observed in the pathophysiology of APS, has prompted studies investigating the relationship between thrombophilic (inherited or acquired) state and pregnancy loss. The current evidence does not allow the inclusion of inherited thrombophilias in the list of etiologies of RM, although several authors have shown a higher prevalence of some hereditary thrombophilias in patients with a history of RM. Recently, studies have demonstrated a higher prevalence of PAI-1 4G/5 G mutations, MTHFR polymorphisms (A1298C and C677T), factor VII polymorphisms, FVL, and prothrombin allelic polymorphisms (A20210G) among populations of women with a history of RM [18, 30-32].

Currently, the international guidelines from reproductive medicine societies who guide the management of RM couples only recommend APS investigation, and discourage screening of inherited thrombophilias or other biomarkers of coagulation disorders [33-36]. The existence of a possible association between inherited thrombophilias and RM has led to intervention studies using heparin (non-fractionated and low molecular weight) associated or not associated with platelet anti-aggregating agents. However, these studies have not been able to reduce the risk of pregnancy loss in these patients [37]. Also, the current international guidelines for management of patients with a history of RM do not outline specific recommendations for women diagnosed with PCOS (RM and PCOS) [33-36].

Some authors argue that there is a higher prevalence of inherited thrombophilias in patients with RM and PCOS. They believe that the lack of evidence for a relationship between RM and inherited thrombophilias is due to studies that include all women with RM. Selecting one specific group of these patients may lead to identification of strong evidence of this relationship. However, despite a small number of studies and patients, the present metaanalysis of the reviewed literature corroborates the evidence that there is no relation between inherited thrombophilias and all patients with RM, even in this specific group of patients with PCOS.

Data available in the current literature on women with no established obstetric history suggest a strong relationship of PCOS with increased platelet aggregation and reduced plasma fibrinolytic activity. Elevated platelet numbers and PAI-1 levels, and alteration of other coagulation inhibitors represent some biomarkers in patients with PCOS [15]. 


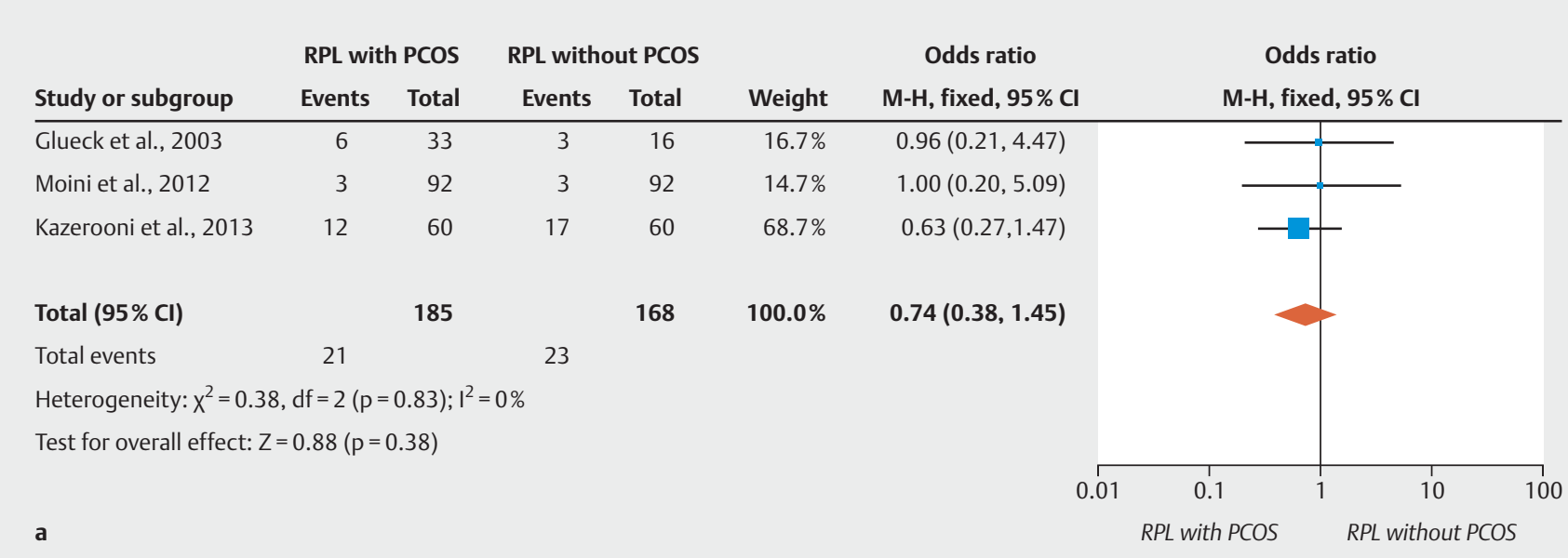

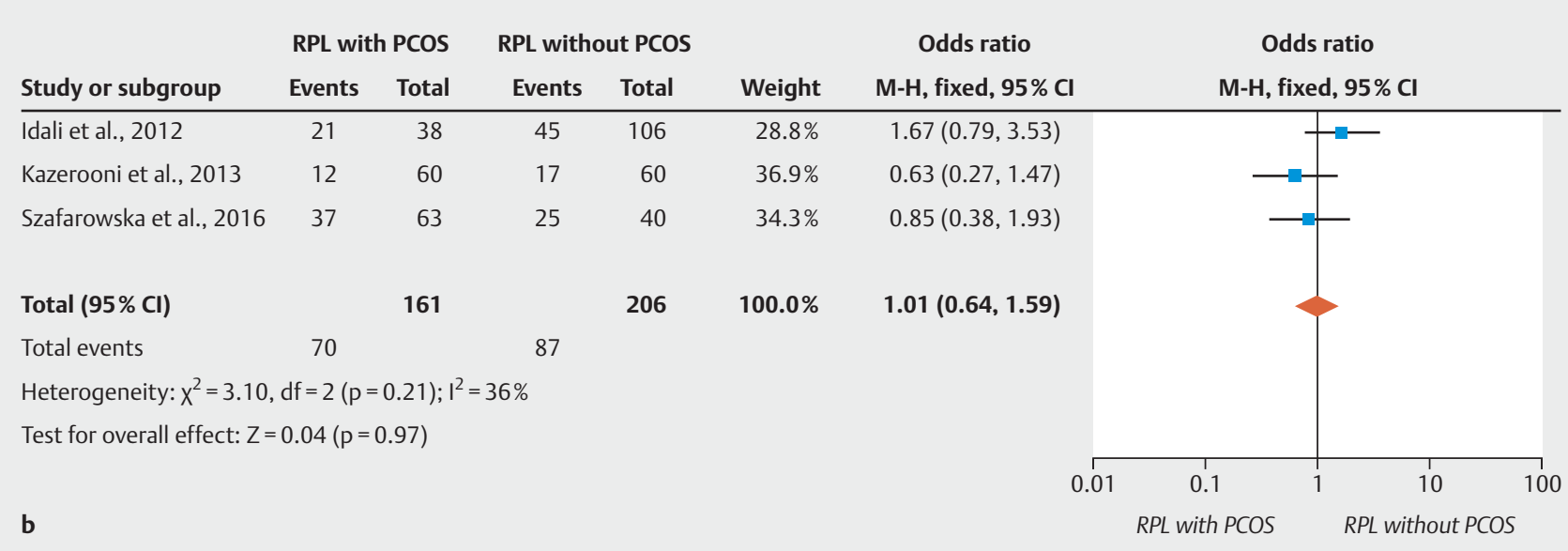

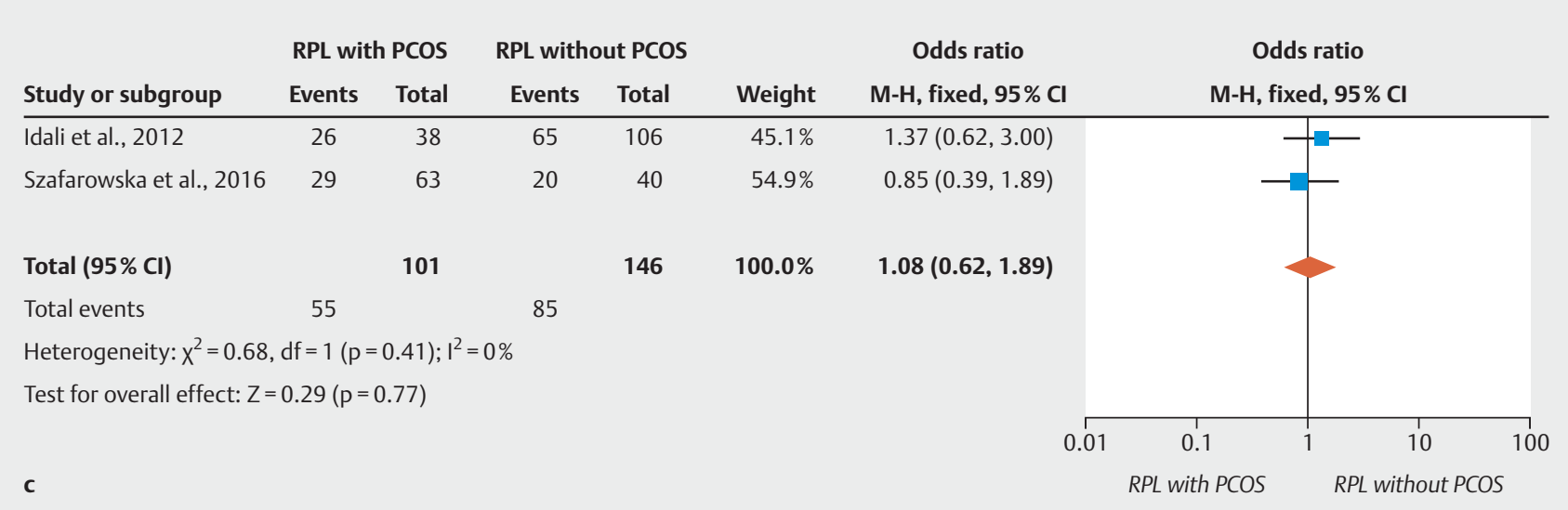

- Fig. 2 a Factor V Leiden meta-analysis. Forest plot for RM with PCOS versus RM without PCOS: recurrent miscarriage. b C677T MTHFR metaanalysis. Forest plot of RM with PCOS versus RM without PCOS: recurrent miscarriage. c A1298C MTHFR meta-analysis. Forest plot of RM with PCOS versus RM without PCOS: recurrent miscarriage.

Among the reviewed studies, PAI is a biomarker that requires more attention. PAI is a factor of the fibrinolytic system that plays relevant roles in hemostatic balance, tissue remodeling, angiogenesis, and reproduction [38]. Gris et al. described high levels of PAI-1 in RM patients compared with healthy pregnant women [39]. Studies of women with PCOS with no established obstetric history revealed a relationship between insulin resistance and increased activity of PAI, corroborating the findings of Kazerooni et al. in a group of patients with RM and PCOS [26, 40,41].

In women with PCOS, PAI was also associated with a greater inflammatory process that is also involved in the etiology of RM [41]. Koiou et al. [40] believe that the highest activity of PAI in 
PCOS patients is dependent on patient body weight, which is elevated in patients with PCOS and obesity. However, Shan et al. [29] and Glueck et al. [23] reported that elevated PAl activity occurs regardless of the patient's body weight.

Recently, reproductive medicine associations published guidelines for the management of PCOS patients. The basic recommendation for these patients includes diet control and physical activity [6]. Furthermore, they showed that metformin improves gestational outcomes in these patients [6]. Some intervention studies in patients with PCOS with no established obstetric history have shown a beneficial effect of metformin use on coagulation biomarkes [42,43]. Burchall et al. [42] observed a decrease in PAI activity in a group of patients with PCOS treated with metformin.

Other PCOS therapeutic options have shown a beneficial effect on gestational outcomes in PCOS patients. The use of liraglutide, a long-acting glucagon-like peptide-1 (GLP-1) analog, in patients with PCOS revealed improved results in cycles of in vitro fertilization and coagulation disorders [43-45]. PCOS patients undergoing bariatric surgery typically present better metabolic control and improved inflammatory status $[46,47]$.

The limitation of this systematic review and meta-analysis is the reduced number of previous publications about this topic. Due to few published studies it was not possible to analyze different biomarkers in this population. To our surprise, this is the first review showing an association between PCOS, recurrent miscarriage, and coagulation disorders. The strength of this present study was to identify possible coagulation biomarkers in recurrent miscarriage patients with PCOS.

The present systematic review reveals that patients with RM and PCOS deserve a differential approach during the evaluation and follow-up during the perigestational period. These patients have a high thromboembolic risk compared with other RM patients. Currently, the small number of available studies did not observe the relationship between inherited thrombophilias and RM patients with PCOS; however, it is not yet possible to rule out this association completely. Procoagulant anomalies are due to PCOS metabolic aberrations. Clinical studies are required to investigate possible biomarkers of clotting disorders in patients with RM and PCOS. It is also important to propose intervention studies with drugs to reduce insulin resistance, such as metformin, GLP-1 analogs, sodium-glucose cotransporter-2 inhibitors, and dipeptidyl peptidase-4 inhibitors, either associated or not associated with anticoagulant therapies.

\section{Conflict of Interest}

The authors declare that they have no conflict of interest.

\section{References}

[1] Stein IF, Leventhal ML. Amenorrhea associated with bilateral polycystic ovaries. Am J Obstet Gynecol 1935; 29: 181-191

[2] Azziz R, Adashi EY. Stein and Leventhal: 80 years on. Am J Obstet Gynecol 2016; 214: 247.e1-247.e11

[3] Stein IF, Cohen MR. Surgical treatment of bilateral polycystic ovariesAmenorrhea and sterility. Am J Obstet Gynecol 1939; 38: 465-480
[4] Bozdag G, Mumusoglu S, Zengin D et al. The prevalence and phenotypic features of polycystic ovary syndrome: A systematic review and metaAnalysis. Hum Reprod 2016; 31: 2841-2855

[5] Azziz R. Epidemiology and genetics of the polycystic ovary syndrome in adults - UpToDate. Online: https://www.uptodate.com/contents/epidemiology-and-genetics-of-the-polycystic-ovary-syndrome-in-adults; last access: 06.11.2018

[6] Teede HJ, Misso ML, Costello MF et al. Recommendations from the international evidence-based guideline for the assessment and management of polycystic ovary syndrome. Fertil Steril 2018; 110: 364-379

[7] Cooney LG, Dokras A. Beyond fertility: polycystic ovary syndrome and long-term health. Fertil Steril 2018; 110: 794-809

[8] Anagnostis P, Tarlatzis BC, Kauffman RP. Polycystic ovarian syndrome (PCOS): Long-term metabolic consequences. Metabolism 2018; 86: 3343

[9] Zegers-Hochschild F, Adamson GD, Dyer S et al. The International Glossary on Infertility and Fertility Care, 2017. Fertil Steril 2017; 108: 393406

[10] Rasmark Roepke E, Matthiesen L, Rylance R et al. Is the incidence of recurrent pregnancy loss increasing? A retrospective register-based study in Sweden. Acta Obstet Gynecol Scand 2017; 96: 1365-1372

[11] El Hachem H, Crepaux V, May-Panloup P et al. Recurrent pregnancy loss: current perspectives. Int J Womens Health 2017; 9: 331-345

[12] Chakraborty P, Goswami SK, Rajani S et al. Recurrent Pregnancy Loss in Polycystic Ovary Syndrome: Role of Hyperhomocysteinemia and Insulin Resistance. PLoS One 2013; 8: e64446

[13] Matjila M], Hoffman A, van der Spuy ZM. Medical conditions associated with recurrent miscarriage-Is BMI the tip of the iceberg? Eur J Obstet Gynecol Reprod Biol 2017; 214: 91-96

[14] Tziomalos K, Dinas K. Obesity and Outcome of Assisted Reproduction in Patients With Polycystic Ovary Syndrome. Front Endocrinol (Lausanne) 2018; 9: 149

[15] Targher G, Zoppini G, Bonora E et al. Hemostatic and fibrinolytic abnormalities in polycystic ovary syndrome. Semin Thromb Hemost 2014; 40: 600-618

[16] Manneras-Holm L, Baghaei F, Holm G et al. Coagulation and fibrinolytic disturbances in women with polycystic ovary syndrome. J Clin Endocrinol Metab 2011; 96: 1068-1076

[17] Burchall GF, Piva T], Linden MD et al. Comprehensive Assessment of the Hemostatic System in Polycystic Ovarian Syndrome. Semin Thromb Hemost 2015; 42: 55-62

[18] Wolski H, Barlik M, Drews K et al. Contribution of inherited thrombophilia to recurrent miscarriage in the Polish population. Ginekol Pol 2017; 88: 385-392

[19] Karadağ C, Yoldemir T, Karadağ SD et al. Obstetric outcomes of recurrent pregnancy loss patients diagnosed with inherited thrombophilia. Ir J Med Sci 2017; 186: 707-713

[20] Schreiber K, Sciascia S, de Groot PG et al. Antiphospholipid syndrome. Nat Rev Dis Prim 2018; 4: 17103

[21] Arachchillage D, Makris M. Inherited Thrombophilia and Pregnancy Complications: Should We Test? Semin Thromb Hemost 2018. doi:10.1055/s-0038-1657782

[22] Moher D, Liberati A, Tetzlaff ] et al.; PRISMA Group. Preferred reporting items for systematic reviews and meta-analyses: the PRISMA statement. BMJ 2009; 339: b2535

[23] Glueck C], Wang P, Bornovali S et al. Polycystic ovary syndrome, the G1691A Factor $V$ Leiden mutation, and plasminogen activator inhibitor activity: Associations with recurrent pregnancy loss. Metabolism 2003; 52: 1627-1632 
[24] Idali F, Zareii S, Mohammad-Zadeh A et al. Plasminogen Activator Inhibitor 1 and Methylenetetrahydrofolate Reductase Gene mutations in Iranian Women with Polycystic Ovary Syndrome. Am J Reprod Immunol 2012; 68: 400-407

[25] Moini A, Tadayon S, Tehranian A et al. Association of thrombophilia and polycystic ovarian syndrome in women with history of recurrent pregnancy loss. Gynecol Endocrinol 2012; 28: 590-593

[26] Kazerooni T, Ghaffarpasand F, Asadi N et al. Correlation between thrombophilia and recurrent pregnancy loss in patients with polycystic ovary syndrome: A comparative study. J Chinese Med Assoc 2013; 76: 282288

[27] Rogenhofer N, Engels L, Bogdanova $\mathrm{N}$ et al. Independent association of the M2/ANXA5 haplotype with recurrent pregnancy loss (RPL) in PCOS patients. Metabolism 2013; 62: 1057-1060

[28] Szafarowska M, Segiet A, Jerzak MM. Methylenotetrahydrololate reductase $\mathrm{A} 1298 \mathrm{C}$ and $\mathrm{C} 677 \mathrm{~T}$ polymorphisms and adverse pregnancy outcome in women with PCOS. Neuro Endocrinl Lett 2016; 37: 141-146

[29] Shan Y, Wang A, Sun Y et al. Coagulation and fibrinolytic indices during the first trimester of pregnancy in women with polycystic ovary syndrome: A preliminary study. Reprod Sci 2013; 20: 1390-1397

[30] Li X, Liu Y, Zhang R et al. Meta-analysis of the association between plasminogen activator inhibitor-1 4G/5G polymorphism and recurrent pregnancy loss. Med Sci Monit 2015; 21: 1051-1056

[31] Turki RF, Assidi M, Banni HA et al. Associations of recurrent miscarriages with chromosomal abnormalities, thrombophilia allelic polymorphisms and/or consanguinity in Saudi Arabia. BMC Med Genet 2016; 17 (S1): 69

[32] Barlik M, Seremak-Mrozikiewicz A, Drews K et al. Correlation between factor VII and PAl-1 genetic variants and recurrent miscarriage. Ginekol Pol 2016; 87: 504-509

[33] Davenport WB, Kutteh WH. Inherited Thrombophilias and Adverse Pregnancy Outcomes. Obstet Gynecol Clin North Am 2014; 41: 133-144

[34] Toth B, Würfel W, Bohlmann M et al. Recurrent Miscarriage: Diagnostic and Therapeutic Procedures. Guideline of the DGGG (S1-Level, AWMF Registry No.015/050, December 2013). Geburtsh Frauenheilk 2015; 75: 1117-1129
[35] Kaiser ], Branch DW. Recurrent Pregnancy Loss. Clin Obstet Gynecol 2016; 59: 464-473

[36] Huchon C, Deffieux X, Beucher G et al. Pregnancy loss: French clinical practice guidelines. Eur J Obstet Gynecol Reprod Biol 2016; 201: 18-26

[37] de Jong PG, Goddijn M, Middeldorp S. Antithrombotic therapy for pregnancy loss. Hum Reprod Update 2013; 19: 656-673

[38] Ye Y, Vattai A, Zhang X et al. Role of Plasminogen Activator Inhibitor Type 1 in Pathologies of Female Reproductive Diseases. Int J Mol Sci 2017; 18: 1651

[39] Gris JC, Neveu S, Mares P et al. Plasma fibrinolytic activators and their inhibitors in women suffering from early recurrent abortion of unknown etiology. J Lab Clin Med 1993; 122: 606-615

[40] Koiou E, Tziomalos K, Dinas K et al. Plasma plasminogen activator inhibitor-1 levels in the different phenotypes of the polycystic ovary syndrome. Endocr J 2012; 59: 21-29

[41] Ye Y, Vattai A, Zhang $X$ et al. Role of Plasminogen Activator Inhibitor Type 1 in Pathologies of Female Reproductive Diseases. Int J Mol Sci 2017; 18: 1651

[42] Burchall G, Piva T, Ranasinha S et al. Differential Effects on Haemostatic Markers by Metformin and the Contraceptive Pill: A Randomized Comparative Trial in PCOS. Thromb Haemost 2017; 117: 2053-2062

[43] Kahal H, Aburima A, Ungvari T et al. The effects of treatment with liraglutide on atherothrombotic risk in obese young women with polycystic ovary syndrome and controls. BMC Endocr Disord 2015; 15: 14

[44] Tzotzas T, Karras S, Katsiki N. Glucagon-Like Peptide-1 (GLP-1) Receptor Agonists in the Treatment of Obese Women with Polycystic Ovary Syndrome. Curr Vasc Pharmacol 2017; 15: 218-229

[45] Salamun V, Jensterle M, Janez A et al. Liraglutide increases IVF pregnancy rates in obese PCOS women with poor response to first-line reproductive treatments: a pilot randomized study. Eur J Endocrinol 2018; 179: 1-11

[46] Skubleny D, Switzer NJ, Gill RS et al. The Impact of Bariatric Surgery on Polycystic Ovary Syndrome: a Systematic Review and Meta-analysis. Obes Surg 2016; 26: 169-176

[47] Escobar-Morreale HF. Surgical management of metabolic dysfunction in PCOS. Steroids 2012; 77: 312-316 